\title{
DISASTER GOVERNANCE AND AUTOCRATIC LEGITIMATION IN BANGLADESH
} Aiding autocratization?

\author{
Maren Aase
}

\section{Introduction}

Bangladesh is among the most disaster vulnerable countries in the world (Behlert et al., 2020). Yet, steady expansion of response capacity to recurrent hazards, including floods and cyclones, has impressed many. During the past 15 years, attainments such as a decline in recorded cyclone deaths, innovative warning systems, fine-tuned crisis policy frameworks, humanitarian engagement, and climate advocacy have earned Bangladesh an international reputation as a rising star within disaster risk reduction (DRR).

However, if Bangladesh ever did live up to this label, this is certainly not the case anymore, when accelerating autocratization prevents enlightened discussion of risks. In February 2021, Dhaka activists protested over the death in jail of writer Mushtaq Ahmed whom the police had arrested for criticizing pandemic preparedness (Mahmud, 2021). The government framed his and similar arrests as legitimate security measures for preventing corona virus 'rumours' that could compromise crisis management. This approach, criticized by human rights organizations for being repressive (AI, 2020; Article19, 2021; HRW, 2020a), displayed a textbook authoritarian disaster response, where autocrats use crises as opportunities to maintain a responsible façade while at the same time curbing dissent (Diamond, 2020).

In light of what therefore seems a dramatic shift in Bangladesh's approach to disasters, this chapter examines the under-explored and uncomfortable possibility that efforts ideally geared towards preventing and tackling disasters can, in fact, also enable autocratization. From a DRR perspective, such questions are critical because autocratization, this chapter demonstrates, intensifies and expands vulnerability and - by fear and by force - suppresses social warning systems, creating vicious circles for disaster risks. How could Bangladesh's disaster governance become so repressive so fast, and with so little criticism from partners home and abroad? Has disaster governance aided autocratization, and if so, how? What consequences does the country's authoritarian disaster response have for its capacity to tackle future risks?

The chapter first introduces relevant concepts and context for exploring the links between disaster governance and autocratization. After that, discussions of responses to cyclone risk, refugee crisis and a pandemic unpack the opportunities that disaster governance provides to 
authoritarian forces, and show how they are seized. Thereafter, the extent to which increased crisis-focus in global development leaves democracy in Bangladesh behind is considered. Lastly, the conclusions summarize the bleak prospects for comprehensive risk reduction in a state that suppresses core disaster preventive mechanisms such as free speech and real elections.

\section{Concepts and context: the risk-creating politics of disaster governance in Bangladesh}

Research documenting Bangladesh's path to autocratic rule has concentrated on constitutional mechanisms and institutions (Riaz, 2019; Riaz and Parvez, 2021). The following focus on disaster governance opens for further discussion how additional processes and actors, including foreign aid, can also enable autocratization.

\section{Disasters, risks and responses}

Bangladesh is a hot spot for disaster risks. Disaster risks are inherently social products of vulnerability, exposure to hazards, and capacity to anticipate and tackle crises with disastrous potentials. Disasters (involving large-scale destruction or fatalities) only materialize when vulnerable people and places are exposed to human-made or natural hazards that states and societies lack the will or ability to protect them from (Wisner, 2016).

Bangladesh's capacity for disaster management has improved radically since Independence, which in part was catalyzed by West Pakistan's callous response to the historically fierce 1970 cyclone that washed away between 250,000 and 500,000 lives. Protective investments include direct (cyclone shelters, flood warning, earthquake drills) and indirect (public health, building codes, poverty reduction) measures. Bangladesh has also pursued a policy shift from single responses to comprehensive risk reduction. Many risks remain though, and new ones develop: The global textile industry has increased workplace risks (Hossain, 2019c). Donorsupported infrastructure development has negatively affected ecology. Unchecked global trade and regional crises have presented complex transboundary challenges such as climate change, refugee influx and health hazards.

Bangladesh's risk realities demonstrate the value of disaster governance, meaning actors, norms and practices concerned with processes that drive or protect against disasters (Forino et al., 2018). Because the crises later discussed are of the kinds that carry disastrous potentials, associated crisis management practices are conceptualized as sub-ventures of disaster governance.

The normative presentation of disaster governance can be worlds apart from its real effects (Barnett, 2013; Hilhorst, Boersma and Raju, 2020). Aid and government analyses rarely discuss unintended impacts. DRR receives far more attention than disaster risk creation (DRC) (Lewis and Kelman, 2012). Conventional disaster governance routinely fails to include disaster-affected people in planning and evaluation, while repressive governance actors actively keep people and practices that can compromise them at bay.

\section{Domestic disaster politics}

Disasters have shaped Bangladeshi politics ever since the dawn of Independence. The painful experiences of the 1970 cyclone Bhola and the 1974 famine, Hossain $(2018$, 2019a) has shown, stimulated a social contract through which elites would prioritize the basic welfare of people. Disaster management became a prioritized issue, and protection in situations of disaster a symbol of independence and citizenship. 
Ability to make performance personal is key. After the Ershad military regime's 1990 fall, the two major political parties, Bangladesh National Party (BNP) (founded by its present leader's late husband; currently in opposition) and the Awami League (AL) (founded by its current leader's late father; presently in office) and their various blocks have (with some intermissions), competed in turbulent elections, and alternated in power. Because few political differences exist between the two, ideologies of nationhood (Hossain, 2019b) and each party's lineage to towering figures in Bangladesh's political history have become emotionally powerful resources. Political networks combine patronage and patriotism to mobilize supporters, and various governments install personalized mechanisms such as the Prime Minister's Relief Fund (Khan and Rahman, 2007).

Confrontational and patronage political realities have stimulated routine blame games and elite manipulation of disaster funds (Mahmud and Prowse, 2012), but also responsive public action. Demonstrating ability to deliver the goods in times of crisis is important for governments, members of Parliament and opposition parties alike, and the electorate values leadership traits such as swift and far-reaching networks (Ruud, 2011). Political competition, a relatively uncensored press, and committed local and international partners have mutually supported each other in advancing disaster management. While no single disaster has ever made a measurable impact on Bangladesh's elections (partly because everyday risks matter more to most than occasional hazards), political leaders nevertheless have reasons to believe that a scandalous disaster response could (Hossain, 2019a; Rubin, 2020).

With the gradual breakdown of electoral democracy, this system is undergoing a silent collapse. For autocrats, disaster response becomes a hybrid arena for keeping up a veneer of accountability, and at the same time a pretext for curbing criticism. Autocracy in a political culture that sees political criticism as personal offence moreover enables state mechanisms such as the 2018 Digital Security Act (DSA) that criminalizes defamation, with blurred or no boundaries between offences against the image of the state and offences against the ruling party. This way, authoritarian rulers can promote a disaster-responsive image while also using pseudo-legal means, corrupt police and packed courts to downplay and deter criticism.

\section{Foreign influence}

Apart from specialized state institutions, notable disaster governance actors in Bangladesh are donors, UN agencies, and local and international development and humanitarian organizations. Norms include UN frameworks for DRR, national regulatory frameworks (promoted by actors such as NGOs or the UNDP) and organizations' codes of conduct. Practices centre on specialized areas such as relief and rehabilitation, where also disaster-affected people, expatriate networks, companies, and social organizations are involved. Other factors include aid policy trends like blurring public-private boundaries, goal expansion associated with the global Sustainable Development Agenda (UNISDR, 2015) and increased results-focus. In theory, that focus can motivate positive effects, yet in practice also stimulate easily measurable (irrelevant, or even harmful) achievement rather than sustainable impact.

\section{Interactions through which disaster governance can aid autocratization}

How, then, does domestic disaster politics and increasingly managerialist foreign influence interact to enable autocratization? Changing aid realities stimulate pragmatism amongst all parties. Bangladesh's aid dependence has declined and its bargaining position has increased. Aid funding increasingly hinges on measurable theories of change that downplay political problems 
of accountability. Moreover, conventional disaster aid, Barnett (2011, p. 221) observes (for humanitarianism) is "hardly a paragon of democratic rule". Autocratic or semi-autocratic donors like China, Saudi Arabia and India are also on the market. When foreign project reports highlight measurable outputs such as numbers of people evacuated and relief packages distributed, domestic political networks can nurture an accountable façade.

Disasters provide opportunities for autocrats to repress political opposition. Yet, no regime can rule by coercion alone, and von Soest and Grauvogel (2017) have shown that autocrats also employ and combine multiple legitimation strategies. Closed regimes mobilize primarily around national identity (for example, saviour narratives) while hybrid regimes prefer procedures, and all stress performance. Below, this chapter will show that in Bangladesh, conventional disaster governance primarily aids autocratization through the supply of performance pointers that autocratic forces can link to, and therefore use to promote an image as a superior, future-oriented, renowned and compassionate liberator and protector.

\section{Disaster governance and autocratic legitimation in practice}

The following are examples from cyclone, refugee crisis and pandemic handling that intersect autocratic processes before and after democratic collapse (see Lührmann and Lindberg, 2019). The examples highlight how disaster governance's risky disaster reductionisms have paved the way for autocratization, produced boosting materials to autocrats and been slow to link disasters and human rights. Examples of authoritarian crisis management also demonstrate that although the present regime goes to lengths to demonstrate efficiency, autocracy is by nature a vicious risk accelerator.

\section{Fifty years of fighting cyclones: power concentration and seizure of simplified success}

In Bangladesh, every biannual 'cyclone season' brings intense storms from the Bay of Bengal that coastal people have to weather. On average, once per third year cyclones reach levels of intensity classified as 'severe'. A few times per decade, fierce cyclones and associated storm surges intersect low-lying delta lands, shallow rivers and funnel-shaped coastlines to trigger large-scale destruction if striking exposed lands and people, especially during high tide.

Forecast and warning systems have steadily improved, increased evacuation, and inspired UN officials and other disaster experts to deem Bangladesh a champion within DRR (Paul, 2009). The key indicator referred for this status is radical decline of recorded cyclone-related fatalities. While the lethal combination of extreme poverty, minimal preparation and recordhigh storm surges led past cyclones to claim hundreds of thousands of lives, fewer cyclone fatalities followed later. After 2007 Cyclone Sidr, with wind speeds up to $240 \mathrm{~km} / \mathrm{h}$, several analysts compared the death toll (between 4,000 and 10,000) to past catastrophes; the 1970 cyclone Bhola and 1991 cyclone Gorky (138,000 fatalities), and theorized that Bangladesh had become significantly better at saving lives in the face of cyclones. These appraisals marked the beginning of a success narrative premised on considering Cyclone Sidr in juxtaposition to past cyclones, thus emulating a natural experiment without controlling either for natural factors such as landfall timing (high tide can, for example, increase storm surges and more than double impact) or for root social factors apart from mitigation issues.

Despite Paul's (2009) methodological critique of these comparisons, the narrative travelled further, into authoritative texts such as the 2014 Human Development Report, which first signalled success and thereafter attributed it to formal disaster governance measures: 
a severe cyclone in 1991 caused nearly 140,000 deaths, while a 2007 cyclone of similar magnitude killed 4,234 people. The reduction in cyclone-related deaths was achieved mainly by improving early warning systems, developing shelters and evacuation plans, constructing coastal embankments, maintaining and improving coastal forest cover and raising awareness at the community level.

(UNDP, 2014, p. 107)

Sustained use of questionable cyclone event comparisons as evidence for a trend is unsurprising because aid analyses are increasingly wired to emphasize inspiring results that enable the sector to renew engagements. Linking capability to tackle cyclones with growing concerns for extreme weather, for example, the state and aid partners used the policy window opened by Cyclone Sidr to establish climate-funding mechanisms.

Downplayed, however, are problems that affected people have to battle in the shadow of success, some of them fashioned by a disaster management system that looks better on paper than it works in practice. For example, many Sidr-affected people just barely survived with help from neighbours with slightly sturdier houses, because public shelters were too few, too far away, in too dangerous conditions or full. Invisible is also the supply of financial and technical means that (government, bureaucratic and NGO) elites can seize to manipulate post-cyclone relief and recovery (Aase, 2020; Nadiruzzaman and Wrathall, 2015). Lastly, development strategies that have concentrated political power on few hands (van Schendel, 2009) are shielded from review. Illustrative here is coastal land transformation for shrimp exports and associated embankment construction near the Sundarbans mangrove forest, in part framed as flood mitigation. These choices have incentivized saline water intrusion, corruption, displacement and exploitation of landless people, and other risk multipliers that also increase floods and cyclone danger. Yet, plans continuously present embankments as protective, and now promote them as climate adaptation (Dewan, 2020).

During the past decade, the idea of Bangladesh as a DRR champion took the shape of a never-ending story. With every new (and most of them weaker and with a less dangerous path and timing than, for example, the 1991 or the 2007) cyclone, the system has been presented by disaster governance actors and analysts as having passed a test, while it in reality has passed smaller-scale (but also important) preparedness challenges. Opportunities for constant gratification suit aid for reasons discussed. They also, however, suit autocrats.

Recently, the current regime seized the simplified success story: Ironically, Cyclone Sidr hit during the controversial reign of the (in part donor encouraged) military-backed 20062008 Caretaker government that coordinated the response. The same government also clumsily and unsuccessfully tried to 'clean' politics by jailing the two major political party leaders for corruption charges. In the election manifesto speech held prior to the 2018 rigged (Riaz and Parvez, 2021) elections, the ruling party made no reference to this period. Blaming the opposition for the 1991 cyclone fatalities was confrontational politics as usual, as was connecting disasters and shame, claiming that previous rulers had "turned Bangladesh into a dependent and beggar country" and a "symbol of flood, drought, cyclones" (BDAL, 2018). Later, however, the party in power - at a time when opposing its image was becoming increasingly dangerous - also seized the aid-created success narrative premised on decline in fatalities that can only be explained by many and much more complex and combined factors than political leadership, if at all. For example, answering the opposition's criticism of the 2020 coronavirus response, the Information Minister used the never-ending rationale discussed above to claim that "Hasina [the PM] handled all disasters" (TIB, 2020b), thus converting "country performance' into personal and 'evidenced' delivery. 
Bangladesh has now reached a dangerous situation where the stakes for upholding success are likely to lead to higher control over natural hazard narratives. It has also reached a situation where disaster death tolls of earlier magnitude appear unthinkable, which is untrue and no good news considering, for example, climate change or the state's recent relocation (discussed below) of thousands of refugees to a cyclone-exposed island. The disaster governance narrative that Bangladesh's aid partners have co-produced, in part to inspire more and better DRR action, has contributed to this situation.

\section{The 2017 Rohingya refugee crises: maximizing humanitarian performance}

In August 2017, crackdowns against Rohingya (predominantly Muslim) minorities that Myanmar had discriminated against and denied citizenship for decades escalated into attempted ethnic cleansing. Organized murder, rape and village burning forced more than 700,000 refugees to flee to Bangladesh. Bangladeshi society responded with solidarity and spontaneous help. The AL Government (whose 2014 victory manifested in part because the opposition distrusted the possibility of actual competition, and boycotted them) formalized the response, and displayed sympathy with victims whose story echoed Bangladesh's own struggle for Independence while underscoring that support would be temporary until refugees could return home. The state built camps, provided relief and organized collaborations with local and transnational aid actors (Lewis, 2019).

The responsibility that Bangladesh took to protect the Rohingyas - that few else, including the UN, had previously shown (Zarni, 2019) - received much acclaim. In September 2017, a British television report from a refugee camp called the PM the 'Mother of Humanity'. This label, which appeared tailor-made for the ruling party's political heritage story and complemented a determined daughter's narrative with motherly softness and care, soon appeared beneath the PM's images on roadside campaign posters. Shortly after, the Cabinet approved a Mother of Humanity Award (which the PM 'refused' to progress in her own name), where local government bodies could nominate persons committed to social causes all over the country and awardees would receive a gold medal and a Tk 200,000 cheque.

The crisis also enabled the (officially secular) Government to validate ordinary people's faith-based solidarity with the Rohingyas and protect Islam during a phase where it courted religious groups such as the radical Hefazat-i-Islami to broaden its support base. Meanwhile, the rapidly deteriorating human rights situation driven by the party machinery itself received limited attention. In December 2018, the PM's efforts for the Rohingya cause earned her the Inter Press Service's International Achievement Award and the Global Hope Coalition's Special Distinction Award for Leadership. These New York events took place only six weeks after the ruthless arrest of renowned photographer Shahidul Alam (for press coverage of the 2018 road safety protests) exposed the regime's hardline approach to critics globally (Ahmed, 2018; Hasan and Wadud, 2020), and made domestic headlines prior to the general elections in December the same year (The Daily Star, 2018).

After the AL had secured another electoral victory, the Government's approach changed, and borders were closed. About 1.2 million refugees in poor and packed refugee camp conditions had brought concerns such as public resource stress, employment tensions, and potential radicalization. After several futile (including forced) repatriation attempts, the Government took up its previously initiated plan to relocate 100,000 refugees to the remote and highly cyclone-exposed Bhasan Char island, which previously had been abandoned after criticism from human rights activists. Bhasan Char was 'developed' through contracts officially worth over US\$300 million, resulting in concrete houses, cyclone shelters, energy infrastructures, livelihood facilities, and 
new state-business connections. Refugees have overall, however, refused to relocate. A study by Zaman et al. (2020) found that 90 per cent of Rohingya respondents opposed relocation, citing the unique vulnerability of the less than 20 -year-old silt island to cyclones and tidal flooding as primary reasons. The UN and rights groups have insisted that independent experts assess the relocation's feasibility, but no unconditional access has been granted.

In 2020, the Government effected the relocation of some thousand refugees, and used the coronavirus as an argument to speed up the process. Overall, observers have refuted official claims that all resettled refugees have consented freely (DW, 2021). Some agreed to go due to uncertain pull factors such as hearing that the island would have more facilities than provided in camps. There are, however, reports of ruthless push factors such as having one's name appear on official relocation lists with no explanation, or being threatened, forced or bribed into "consent", and transportation, by public officials (McPherson and Paul, 2020).

Rights groups have claimed that life on Bhasan island involves dire living conditions, sexual harassment by the Navy and contractors, restricted freedom of movement and free speech, and violent retaliation for protest. Naval and government spokespersons have denied the allegations, saying that the Rohingyas are guests that are taken care of (Hossain, 2020). To justify the relocation, officials draw on Bangladeshi culture for resilience and gratitude. Ministers uphold that cyclones are part of ordinary coastal life, that solid structures are better than temporary tents, and that the island facilities are better than anything available to millions of impoverished Bangladeshis. This attitude is hard to distinguish from conventional disaster aid that routinely empowers privileged people to determine the acceptable risks of poor and unconsulted others.

The international community's failures to address Myanmar's brutality towards the Rohingyas along with its excessive praise of Bangladesh have aided identity-based autocratic legitimation and helped the Government into a position from where it now, through the relocations, can demonstrate its long-sought superiority of ends over means.

\section{The Covid-19 pandemic: 'responsible' repression in the time of Corona}

In March 2020, the coronavirus that triggered the Covid-19 pandemic was found in Bangladesh. After initial reluctance, the Government took diverse lockdown measures to control the spread of the virus. Narrative control soon followed. A private university's pressure against a researcher to withdraw his scientifically modelled Covid-19 predictions was the first sign that the response would be anything but open and informed. Along with China, Egypt and Venezuela, Bangladesh became a pioneer in curbing criticism, belittling expertise and criminalizing inconvenient facts or opinions, framed as 'covid rumours' (HRW, 2021a). The state means applied were wide-ranging:

The Government issued a circular on May 7, banning all government employees from posting, "liking," sharing, or commenting on any content which might "tarnish the image of the state" or the Government's "important persons," warning that violation of this order would result in legal action. The authorities have increased surveillance of anyone who might spread "rumors," and has ramped up media censorship. The Rapid Action Battalion (RAB), the country's primary counterterrorism unit, recently formed a "cyber verification cell" to identify Covid-19 "rumors."

(HRW, 2020b)

The regime never had to declare a state of emergency in order to control dissent, because the executive already had empowered itself by passing the deliberately vague 2018 Digital Security 
Act (DSA) which enables the politically penetrated state to curb criticism. Through the DSA, online expressions 'found to' create instability or offend the state can be punished with up to 10 years in prison, or life sentence (for repeated "offences"). Its arbitrary and excessive use is inconsistent with human rights law requirements for legality, non-discrimination and proportionality (AI, 2018; Carmalt and Dale, 2012).

Efficient crisis response depends upon combining capacity and trust (Christensen et al., 2016). Pandemics are different from Bangladesh's 'usual' disasters because their management demands higher, and longer-term, score on both dimensions. Social distancing is particularly difficult for millions of people living in poverty who lack access to protective equipment, testing, treatment and crisis assistance and cannot afford to ignore subsistence. Knowing this, and knowing that starvation is more damaging to legitimacy than a quiet pandemic, the state relaxed public health restrictions in practice. A study by Ali, Hassan and Hossain (2021) found that ordinary people's non-compliance was widely tolerated, and that upholding protective legitimacy with citizens took priority over pandemic management. Due to low testing and generally unreliable data, the extent to which this approach cost or shielded lives is indiscernible.

Its hard line approach to state critics and lenient approach on the ground illustrate that the regime prioritized its own survival over public safety. In theory, concerns raised by persons arrested under the DSA could have improved relief, informed the 'war' against the virus, or supplied ideas for post-crisis economic restructuring. In practice, the risk that critics also could have exposed an underfunded and corrupt health system (where certificates can be bought and funding pocketed, see Al-Zaman, 2020) and compromised the interests of regime supporters, became too high.

Nine months after his arrest under the DSA for criticizing shortage of protective equipment for healthcare workers and for sharing a drawing from (also arrested and tortured) cartoonist Kishore's "Life in the time of corona" series on Facebook, Mushtaq Ahmed died in pre-trial custody (HRW, 2021b). The regime's excessive force against critics has long been an open secret. Yet, Ahmed's death and pandemic repression presented new trials for autocratic legitimacy because the global pandemic had high salience across the world and human rights watchdogs increasingly engage with disaster issues. The UN is now pressurizing Bangladesh on revising the DSA. Domestically, post-pandemic economic crisis may challenge the performance legitimacy that the Government prioritized in the first active phase of the pandemic. Large-scale and (due to supply via India) relatively early Covid-19 vaccinations can lower the challenge, and reductionist reports of 'impressive' disaster response efforts by an earlier developing country might be expected in the years to come.

\section{Leaving democracy behind?}

The following section lifts the gaze from specific crises discussed thus far, to reflect on the broader links between the merging of disaster and development taking place under the 2030 Sustainable Development Goals (SDG) agenda, and autocratization. Due to multiple risks associated with climate change, Bangladesh's strategic role for foreign improvement projects (Hossain, 2018) is under renewal. This happens while development-related problems increasingly are framed as crises. Calhoun (2004) has warned that this "emergency imaginary" stimulates symptoms treatment over systems change. In this context, free speech and political competition, it seems, can pragmatically be subordinated to urgent crisis action.

The present Government in Bangladesh often uses development jargon to prove crisis commitment abroad while also delivering the charisma needed to mobilize loyalty at home. In 
2021, the government launched the Mujib Climate Prosperity Plan. The name 'Mujib' cultivates a political heritage line from the freedom fighter, first PM, 'father of the nation' or 'friend of Bengal' ('Bangabandhu') Sheikh Mujibur Rahman, to his daughter, the present PM. This imagery uplifts her capacity to lead for the future. Abroad, the plan was 'lauded' by ambassadors and UN personalities for its "transformative climate concept for sustainable economic growth through investing in nature and climate resilience" (TIB, 2020a), thus disconnecting civil rights from sustainability.

The development sector increasingly elevates personal crisis management traits of political leaders. In 2015, the PM was awarded the United Nations Champions of the Earth Award by the UN Environment Programme, for climate advocacy. In 2020, the Guardian's online development section provided a platform for the PM and a CEO for the Global Center on Adaptation, which is a multi-stakeholder advocacy group initiated by former UN General Secretary Ban Ki Moon. On this arena, and in this company, the regime could present its 'fights' with cyclones and the coronavirus, and display sympathetic future-oriented concerns and capacity writing for example that: "as countries we can learn from successes around the world and support each other. It's by pulling together that we will emerge stronger and more resilient" (Hasina and Verkooijen, 2020).

So far, the international scene has been a low-risk arena for the regime. When the Overseas Development Institute hosted the PM's talk on the country's development "policy, progress and prospects" (ODI, 2018), the presenter was shielded from human rights questions (Channel4news, 2018). On (the few) occasions where the government openly has been questioned and even confronted, it has used development success to gloss over the situation. In a TV interview on the state of democracy, the international affairs advisor eluded criticism of enforced disappearances (i.e. unlawful abductions or other liberty-depriving actions that are conducted, and concealed, with direct or indirect support by the state apparatus), with responses such as "that is not our policy" or by deflection by referring to empowerment initiatives (Al Jazeera, 2019). Meanwhile, at home, the ruling party's Centre for Research and Information (CRI) communicates that the PM's policy of "leaving no one behind" (i.e. the slogan of the SDG agenda) reflects the policy of Bangabandhu (bdnews24.com, 2020).

When risk and rights are subordinated to development, autocrats can thrive. However, playing the development card may be less efficient if donor interests are directly challenged. Recently, when an Al Jazeera documentary suggested high-level political association with a surveillance scandal that could jeopardize military interests at home and abroad, the Government accused the news medium of being part of a plot to destabilize "the secular democratic government of Bangladesh with a proven track record of extraordinary socio-economic development and progress" (The Daily Star, 2021). Domestic media in turn publicly conveyed that real journalism on the matter would imply economic or personal risks that could threaten their existence, and the UN initiated investigations.

With stronger international spotlight on its power abuse and a weakened opposition, the regime might opt for a softer approach. Other options include changing the means of oppression or altering the meaning of democracy altogether.

\section{Conclusion}

This chapter has shown that disaster governance has supplied boosting materials for autocratic legitimation in Bangladesh. Governance of disaster processes can concentrate power and misrepresent risk realities, and by combining the two, aid autocratization. Autocrats adapt the performance boosts that disaster governance supplies to support a politically powerful image 
of might and care, and to gloss over the fact that the politicized state apparatus also uses crises opportunities to curb opposition.

In Bangladesh, the vicious circles that autocratization creates for disaster risk need more attention. First, autocratization intensifies existing disaster vulnerabilities of people living in marginal economic and social conditions. When regime-loyal economic elites can elevate themselves above the country's rich environmental and social policies, more risks are also created in the dark. Second, autocratization creates new risks among people who are usually not on disaster governance actors' watch lists, and who, in situations of disaster, can press for efficient response. Bangladeshi writers, students, scholars, artists, activists, journalists, opposition leaders, bloggers, civil servants, public employees and others who call the will, capacity or legitimacy of the powerful into question are now at unprecedented risk of human rights violations ranging from subtle sanctions to arrests, torture and enforced disappearances. Third, self-censorship sweeps valuable information about system dysfunctionalities under the carpet, and increases the distance from the most vulnerable to decision-makers, and humanitarian organizations that operate in restrictive countries trade non-discrimination in exchange for access (Desportes, 2020). Lastly, in the culture of fear that autocratization instils, much-needed serious discussion (Jasanoff, 2010) about future risks becomes illusory. Imminent threats of magnitudes that could overwhelm Bangladesh's capacity - likely co-created by economic interests associated with politics - receive dangerously shallow attention. Imagine, for example, earthquakes in exportprocessing zones, food industry-driven antibiotics resistance or record-high storm surges from deforestation and carbon emissions. Another imminent risk is land-use change-driven transmission of zoonotic viruses such as Nipah - with death rates up to 75 per cent recorded in Bangladesh (Constable, 2021) when only the wealthiest, best connected and least exposed can expect high-quality care.

Bangladesh's disaster warning system is crumbling. At stake is the country's inherently imperfect (Wisner, 2016) yet all the same historically unique capacity to tackle recurrent natural hazards and other crises, progressed by affected peoples, various governments, and committed national and international partners over almost 50 years. At this point in history, when core disaster preventive mechanisms such as free speech and real elections have been stripped away, any assessment of the country as a champion within disaster risk reduction is invalid, hazardously ignorant or simply propaganda.

\section{Bibliography}

Aase, M. (2020) 'Listing for change? Exploring the politics of relief lists in Bangladesh after Cyclone Sidr', Disasters, 44(4), pp. 666-686.

Ahmed, Q. (2018) 'Why did Bangladesh arrest Shahidul Alam?' Al Jazeera Opinion, 9 August [Online]. Available at: www.aljazeera.com/opinions/2018/8/9/why-did-bangladesh-arrest-shahidul-alam (Accessed 10 March 2021).

AI (Amnesty International) (2018) 'Bangladesh: Muzzling dissent online', report, 12 November [Online]. Available at: www.amnesty.org/en/documents/asa13/9364/2018/en/ (Accessed 10 March 2021).

AI (2020) 'Bangladesh: Escalating attacks on the media must stop', Article, 8 October [Online], Available at: www.amnesty.org/en/latest/news/2020/10/bangladesh-escalating-attacks-on-the-media-muststop/ (Accessed 10 March 2021).

Al Jazeera (2019) 'Is Bangladesh a one-party state?', Head to Head, TV programme, 1 March, [Online]. Available at: www.aljazeera.com/program/head-to-head/2019/3/1/is-bangladesh-a-one-party-state/

Al-Zaman, M. S. (2020) 'Healthcare Crisis in Bangladesh during the COVID-19 Pandemic', The American Journal of Tropical Medicine and Hygiene, 103 (4), pp. 1357-1359.

Ali, T.O., Hassan, M. and Hossain, N. (2021) 'The moral and political economy of the pandemic in Bangladesh: Weak states and strong societies during Covid-19', World Development, 137 [Online]. Available at: www.sciencedirect.com/science/article/pii/S0305750X20303430 


\section{Disaster governance and autocratization}

Article 19 (2021) 'Bangladesh: Alarming crackdown on freedom of expression during coronavirus pandemic', Article19.org, 19 May [Online]. Available at: www.article19.org/resources/bangladesh-alarmingcrackdown-on-freedom-of-expression-during-coronavirus-pandemic/ (Accessed 10 March 2021).

Barnett, M. (2011) Empire of Humanity: A History of Humanitarianism. Ithaca, NY: Cornell University Press. Barnett, M. (2013) 'Humanitarian Governance', Annual Review of Political Science, 16, pp. 379-398.

BDAL (2018) [Bangladesh Awami League] 'Election Manifesto 2018, speech by Sheikh Hasina' [Online]. Available at: http://manifesto2018.albd.org/election-manifesto-2018-speech-by-sheikh-hasina/ (Accessed 10 March 2021).

Bdnews24.com (2020) 'Hasina adopted Bangabandhu's policy of leaving no one behind', 21 September [Online]. Available at: https://m.bdnews24.com/en/detail/bangladesh/1803326 (Accessed 10 March 2021)

Behlert, B., Diekjobst, R., Felgentreff, C., Manandhar, T., Mucke, P., Pries, L. Radtke, K., and Weller, D. (2020) World Risk Report 2020. Bündnis Entwicklung Hilft, Ruhr University Bochum: Institute for International Law of Peace and Conflict.

Calhoun, C. (2004) 'A world of emergencies: Fear, intervention, and the limits of cosmopolitan order', Canadian Review of Sociology, 41 (4), pp. 373-395.

Carmalt, J. and Dale, C. (2012), 'Human Rights and Disaster', In Wisner, B., Gaillard, J. C. and Kelman, I. (eds.), Handbook of Hazards and Disaster Risk Reduction, London: Routledge, pp. 55-64.

Channel4news (2018) 'Bangladesh PM refuses to answer questions on human rights record', TV report, 18 April, [Online]. Available at: www.channel4.com/news/bangladesh-pm-refuses-to-answer-questionson-human-rights-record (Accessed 10 February 2021).

Christensen, T., Lægreid, P. and Rykkja, L. H. (2016) 'Organizing for Crisis Management: Building Governance Capacity and Legitimacy’, Public Administration Review, 76, pp. 887-897.

Constable, H. (2021) 'The other virus that worries Asia', BBC Future, January 12 [Online]. Available at: www.bbc.com/future/article/20210106-nipah-virus-how-bats-could-cause-the-next-pandemic (Accessed 10 March 2021).

The Daily Star (2018) 'PM receives 2 int'l awards for hosting Rohingyas', 29 September [Online]. Available at: www.thedailystar.net/rohingya-crisis/news/bangladesh-pm-sheikh-hasina-receivestwo-un-international-awards-hosting-rohingyas-1639951 (Accessed 10 March 2021).

The Daily Star (2021) 'Bangladesh govt terms Al Jazeera report 'false, defamatory and a politically motivated smear campaign', 2 February [Online], Available at: www.thedailystar.net/bangladesh/ news/bangladesh-govt-terms-al-jazeera-report-false-defamatory-and-politically-motivated-smearcampaign-2037929 (Accessed 10 March 2021).

Desportes, I. (2020) Repression Without Resistance: Disaster Responses in Authoritarian Low-Intensity Conflict Settings. Erasmus University Rotterdam.

Dewan, C. (2020) "“Climate change as a spice": Brokering environmental knowledge in Bangladesh's development industry', Ethnos, pp. 1-22 [Online]. Available at: https://www.tandfonline.com/doi/ full/10.1080/00141844.2020.1788109? scroll=top\&needAccess $=$ true

Diamond, L. (2020) 'Democracy Versus the Pandemic. The Coronavirus is Emboldening Autocrats the World Over', Foreign Affairs, 14 June [Online]. Available at: www.foreignaffairs.com/articles/world/ 2020-06-13/democracy-versus-pandemic (Accessed 10 March 2021).

DW (Deutsche Welle) (2021) 'Rohingya: Relocated refugees say life was better at Cox's Bazar', news report, 26 February [Online]. Available at: www.dw.com/en/rohingya-relocated-refugees-say-life-wasbetter-at-coxs-bazar/a-56717730 (Accessed 10 March 2021).

Forino, G., Bonati, S., \& Calandra, L. M. (eds.) (2018) Governance of Risk, Hazards and Disasters: Trends in Theory and Practice (1st ed.). London: Routledge.

Hasan, M., and Wadud, M. (2020) 'Re-conceptualizing safety of journalists in Bangladesh', Media and Communication, 8 (1), pp. 27-36.

Hasina, S. and Verkooijen, P. (2020) 'Fighting cyclones and coronavirus: how we evacuated millions during a pandemic', Op. ed, The Guardian, 3 June [Online]. Available at: www.theguardian.com/ global-development/2020/jun/03/fighting-cyclones-and-coronavirus-how-we-evacuated-millionsduring-a-pandemic (Accessed 10 February 2021).

Hilhorst, D., Boersma, K. and Raju, E. (2020) 'Research on Politics of Disaster Risk Governance: Where Are We Headed?', Politics and Governance, 8 (4), pp. 214-219.

Hossain, A. (2020) 'Rohingya relocated to remote island against their will, rights groups say', BBC news report, 4 December [Online]. Available from: www.bbc.com/news/world-asia-55177688 (Accessed 10 March 2021). 


\section{Maren Aase}

Hossain, N. (2018) The Aid Lab: Understanding Bangladesh's unexpected success. Oxford: Oxford University Press.

Hossain, N. (2019a) 'The 1970 Bhola cyclone, nationalist politics, and the subsistence crisis contract in Bangladesh', Disasters, 42 (1), pp. 187-203.

Hossain, N. (2019b) 'Winner Takes All: Elite Power Struggles and Polarization in Bangladesh', In Carothers T. \& O’Donohue A. (eds.), Democracies Divided: The Global Challenge of Political Polarization (pp. 177-198). Washington, DC: Brookings Institution Press.

Hossain, N. (2019c) 'Rana Plaza, disaster politics, and the empowerment of women garment workers in Bangladesh', Contemporary South Asia, 27 (4), pp. 516-530.

HRW (2020a) 'Bangladesh: End Wave of COVID-19 "Rumor Arrests", HRW news release, 31 March [Online]. Available at: www.hrw.org/news/2020/03/31/bangladesh-end-wave-covid-19-rumorarrests (Accessed 10 March 2021).

HRW (2020b) 'Bangladesh: Mass Arrests Over Cartoons', HRW news release, 7 May, [Online]. Available at: www.hrw.org/news/2020/05/07/bangladesh-mass-arrests-over-cartoons-posts (Accessed 10 March 2021).

HRW (2021a) 'Covid-19 Triggers Wave of Free Speech Abuse', HRW report, 11 February [Online]. Available at: www.hrw.org/news/2021/02/11/covid-19-triggers-wave-free-speech-abuse (Accessed 10 March 2021).

HRW (2021b) 'Bangladesh: Writer Dies After 9 Months in Custody', HRW news release, 26 February [Online]. Available at: www.hrw.org/news/2021/02/26/bangladesh-writer-dies-after-9-monthscustody (Accessed 10 March 2021).

Jasanoff, S. (2010) 'Beyond Calculation: A Democratic Response to Risk', In Lakoff, A. (ed.) Disaster and the Politics of Intervention. New York: Columbia University Press, pp. 14-41.

Khan, M. R. and Rahman, M. A. (2007) 'Partnership approach to disaster management in Bangladesh: A critical policy assessment', Natural Hazards, 41 (2), pp. 359-378.

Lewis, D. (2019), 'Humanitarianism, civil society and the Rohingya refugee crisis in Bangladesh', Third World Quarterly, 40 (10), pp. 1884-1902.

Lewis, J. and Kelman, I. (2012), 'The good, the bad and the ugly: Disaster risk reduction (DRR) versus disaster risk creation (DRC)', PLOS Currents Disasters [Online]. Available at: http://currents.plos.org/ disasters/index.html\%3Fp=1829.htm (Accessed 10 March 2021).

Lührmann, A. and Lindberg, S. I. (2019) 'A third wave of autocratization is here: what is new about it?', Democratization, 26 (7), pp. 1095-1113.

Mahmud, F. (2021), 'Anger in Bangladesh over dissident writer's death in prison', Al Jazeera 26 February [Online]. Available at: www.aljazeera.com/news/2021/2/26/anger-in-bangladesh-over-prominentwriters-death-in-prison (Accessed 10 February).

Mahmud, T. and Prowse, M. (2012) 'Corruption in cyclone preparedness and relief efforts in coastal Bangladesh: lessons for climate adaptation?', Global Environmental Change, 22 (4), pp. 933-943.

McPherson, P and Paul, R. (2020) 'Rohingya coerced into going to remote island, refugees and aid workers say', Reuters, 3 December [Online]. Available at: www.reuters.com/article/us-bangladeshrohingya-idUSKBN28D0RQ (Accessed: 10 March 2021).

Nadiruzzaman, M. and Wrathall, D. (2015) 'Participatory exclusion - cyclone Sidr and its aftermath', Geoforum, 64, pp. 196-204.

ODI (Overseas Development Institute) (2018) Bangladesh's development story: policy, progress and prospects, 17 April [Online seminar]. Available at: www.odi.org/events/4550-bangladesh-s-developmentstory-policy-progress-and-prospects.

Paul, B. K. (2009). 'Why relatively fewer people died? The case of Bangladesh's cyclone Sidr', Natural Hazards, 50 (2), pp. 289-304.

Riaz, A. (2019) Voting in a Hybrid Regime: Explaining the 2018 Bangladeshi election. Singapore: Springer.

Riaz, A. and S. Parvez (2021). 'Anatomy of a rigged election in a hybrid regime: the lessons from Bangladesh', Democratization, 28 (4), pp. 801-820.

Rubin, O. (2020) 'The political dynamics of voter retrospection and disaster responses', Disasters, 44(2), pp. 239-261.

Ruud, A. E. (2011) 'Democracy in Bangladesh: A village view', In Madsen, S. T., Nielsen, K. B. and Skoda, U. (eds.) Trysts with Democracy: Political practice in south Asia. London: Anthem Press, pp. 45-70.

TIB [The Independent Bangladesh] (2020a) 'Hasina's "Mujib Climate Prosperity Plan" lauded globally', 5 February [Online]. Available at: www.theindependentbd.com/post/259026 (Accessed 10 February 2021). 
TIB (2020b) 'Sheikh Hasina aptly handled all disasters: Hasan', 23 July [Online]. Available at: www.theindependentbd.com/post/250669 (Accessed 10 March 2021).

UNDP (2014) Human Development Report 2014: Sustaining Human Progress - Reducing Vulnerabilities and Building Resilience. New York.

UNISDR (United Nations Office for Disaster Risk Reduction) (2015) Disaster risk reduction and resilience in the 2030 agenda for sustainable development. New York: UNHQ Liaison Office.

Van Schendel, W. (2009) A History of Bangladesh. Cambridge: Cambridge University Press.

Von Soest, C. and Grauvogel, J. (2017) 'Identity, procedures and performance: how authoritarian regimes legitimize their rule', Contemporary Politics, 23 (3), pp. 287-305.

Wisner, B. (2016) 'Vulnerability as concept, model, metric and tool', The Oxford Research Encyclopedia of Natural Hazard Science [Online]. Available at: https://oxfordre.com/naturalhazardscience/ view/10.1093/acrefore/9780199389407.001.0001/acrefore-9780199389407-e-25. (Accessed 10 March 2021).

Zaman, S., Sammonds, P., Ahmed, B. and Rahman, T. (2020) 'Disaster risk reduction in conflict contexts: Lessons learned from the lived experiences of Rohingya refugees in Cox's Bazar, Bangladesh', International Journal of Disaster Risk Reduction, 50, pp. 1-17.

Zarni, M. (2019) 'The UN Has Failed the Rohingya in Myanmar. Now it Should Take Responsibility', The Wire, 30 June [Online]. Available at: https://thewire.in/south-asia/united-nations-rosenthalreport-rohingya-myanmar (Accessed 10 March 2021). 